\title{
Kaolen Cevherinden Demirin Aspergillus niger ile Uzaklaştırılması
}

\author{
Olcay KALE ${ }^{1}$, Hasan ÇíFTÇí1 \\ 1Süleyman Demirel Üniversitesi, Mühendislik Fakültesi, Maden Mühendisliği Bölümü, 32260, Isparta
}

(Alınış / Received: 16.07.2019, Kabul / Accepted: 17.02.2020)

\author{
Anahtar Kelimeler \\ Kaolen, \\ Biyoliç, \\ Demir uzaklaștırma, \\ Aspergillus niger, \\ Saflaştırma
}

\begin{abstract}
Özet: Kaolen, kaolenit olarak bilinen hidratlı alüminyum silikat içeren önemli bir endüstriyel hammaddedir. Demir, kaolende önemli safsılılklardan biridir. Kaolende demir oksitlerin bulunması, rengini olumsuz yönde etkiler ve kaolenin parlaklığını ve refrakterliğini azaltır. $\mathrm{Bu}$ nedenle kaolenin çeşitli endüstrilerde kullanılabilmesi için demir içeriği azaltılmalıdır. Bu çalışmada, Aspergillus niger kullanılarak kaolenden demirin biyoliç yöntemi ile giderimi araştırılmıştır. Testlerde katı oranı, sükroz oranı ve farklı sürelerde liç ortamına cevher ilavesinin kaolenden demir giderimine etkileri incelenmiştir. Aspergillus niger ile gerçekleştirilen biyoliç işlemlerinde en yüksek $\mathrm{Fe}_{2} \mathrm{O}_{3}$ uzaklaştırma verimi, \%1 katı oranı ve \%10 sükroz içeren ortamda \%61,09 olarak elde edilmiştir. Katı oranı ve sükroz oranının artışıyla $\mathrm{Fe}_{2} \mathrm{O}_{3}$ giderim verimlerinin düştüğü belirlenmiştir. Fungus gelişimi sonrası liç ortamına kaolen cevherinin ilavesi demir giderimine olumlu etki yapmıştır.
\end{abstract}

\section{Removal of Iron from Kaolin Ore by Aspergillus niger}

Keywords

Kaolin,

Bioleaching,

Iron removal,

Aspergillus niger,

Purification

\begin{abstract}
Kaolin is an important industrial raw material containing hydrated aluminum silicate known as kaolenite. Iron is one of the important impurities in kaolin. The presence of iron oxides in kaolin affects the colour of kaolin negatively and reduces the brightness and refractoriness of kaolin. For this reason, the iron content of the kaolin should be reduced for its use in various industries. In this study, the removal of iron from kaolin by bioleaching method was investigated using Aspergillus niger. In the experiments, the effects of solid ratio, sucrose ratio and ore addition to leaching medium at different times on the iron removal from kaolin were studied. The maximum $\mathrm{Fe}_{2} \mathrm{O}_{3}$ removal yield in the experiments with Aspergillus niger was determined as $61.09 \%$ at $1 \%(\mathrm{w} / \mathrm{v})$ solid and $10 \%(\mathrm{w} / \mathrm{v})$ sucrose. Increasing the solid ratio and sucrose concentration were observed to produce an adverse effect on the removal of $\mathrm{Fe}_{2} \mathrm{O}_{3}$. Addition of kaolin ore after fungal development to leaching medium had a positive effect on iron removal.
\end{abstract}

\section{Giriş}

Kaolen; granit ve diğer magmatik/volkanik kayaçların bozunmaları sonucu oluşan ve ana minerali kaolenit olan önemli bir endüstriyel hammaddedir [1]. Feldspatların fiziksel etmenlere maruz kalarak bozunması sonucunda, kendi formunu kaybederek kaolenleşme meydana gelmekte ve kaolenin yapı taşı olan kaolenit minerali $\left(\mathrm{Al}_{2} \mathrm{Si}_{2} \mathrm{O}_{5}(\mathrm{OH})_{4}\right)$ oluşmaktadır. Diğer kil mineralleri ise kaolenlerden türemiştir [2]. Bu tür kil mineralleri kaolen kadar saf halde değildirler ve genellikle hidrotermal tortularda kaolenit ile birlikte bulunurlar [1].
Dünya kaolen tüketiminde birinci sırayı kağıt sanayi almaktadır (Şekil 1). Avrupa'da kağıt dolgu maddesi olarak toplam kaolen tüketiminin \%40'ı, ABD'de ise \%80'i kullanılmaktadır. En çok tüketimin yaşandığı diğer sanayi dalları ise; boya, seramik ve plastik sektörleridir. Bunların dışında lastik sanayinde maliyet düşürücü ve plastikleri güçlendirme amacı ile, mürekkep yapımında parlaklığı koruma ve cam elyaf yapımında yalıtım amaçlı kullanılmaktadır. Ayrıca oksitlenmiş yüzeylerin temizlenmesinde, otomobil ve metal parlatıcılarda, yalıtımda alçı panellerde, diş macunlarında, daha iyi akıcılık için su bazlı yapıștırıcılarda ve absorpsiyon özelliğinden dolayı bazı ilaçlarda kullanılmaktadır [3]. 
Kaolen, gelişmiş ülkelerde ağırlıklı olarak seramik ve kağıt sektörlerinde kullanılmasına rağmen, ülkemizde ise büyük bir oranda (yaklaşık \%80'i) çimento sektöründe tüketilmektedir. Bunun nedeni ülkemizdeki kaolenlerin kağıt ve diğer sektörlerde kullanılabilmesi için gerekli bazı özellikleri sağlamamasından kaynaklanmaktadır. Ülkemizde kaolenlerin özellikle demir içeriğinin fazla olması nedeniyle \%90'ın üzerinde beyazlık değerini sağlayamadığı için seramik ve kağıt sektörlerinde kullanılamamaktadır. Zenginleştirme süreçlerinden geçirilmemiş kaolenler, düşük fiyatlarla ihraç edilmektedir. Ayrıca ülkemizde ihtiyaç duyulan kaplama kaolenler yurtdışından ithal edilmektedir. Ülkemizdeki kaolenlerin istenilen özelliklere göre zenginleştirilmesi sonucunda kağıt, seramik ve diğer sektörler için kullanımı arttırılabilir [4].

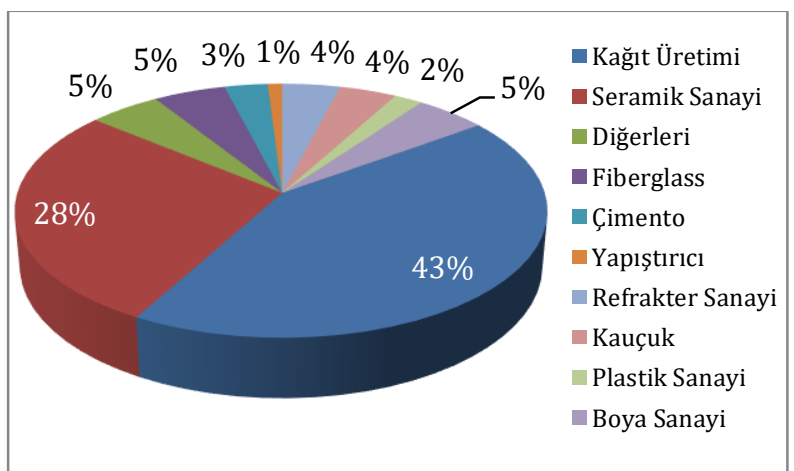

Şekil 1. Dünya kaolen tüketiminin sektörel dağılımı [5]

Kaolenin kağıt, plastik vb. gibi çeşitli endüstrilerde kullanılabilmesi için bünyesinde bulundurduğu safsızlıkların fiziksel, kimyasal veya biyolojik yöntemler ile uzaklaștırılması gerekmektedir. Yüksek Alan Şiddetli (YAŞ) manyetik ayırma, indirgeyici liç, ozonlama, flotasyon gibi hem fiziksel hem de kimyasal yöntemler kaolenden çeşitli safsızlıkları uzaklaştırmak için uygulanan yöntemlerdir [6]. Kaolenin zenginleștirilmesinde genel olarak yaş yöntemler (Şekil 2) seçilse de nadiren kuru zenginleştirme yöntemleri de kullanılmaktadır. Böylelikle kaolenin bünyesinde barındırdığı feldspat, kuvars, demir, mika, titanyum ve sülfatlı bileşikler gibi istenmeyen mineraller uzaklaştırılmaktadır [79].

Kaolenden demirin biyolojik yöntemle gideriminde organik asit (oksalik asit, sitrik asit vb.) üretimini sağlayan ve/veya demiri indirgeyen mikroorganizmalar kullanılır. $\mathrm{Bu}$ yöntem yeni ve alternatif bir prosestir. Sülfür cevherlerinin/ konsantrelerinin biyoliç/ biyooksidasyon proseslerinde genellikle Acidithiobacillus ferrooxidans, Leptospirillum ferrooxidans ve Acidithiobacillus thiooxidans türü mikroorganizmalar kullanılmaktadır [10]. Fakat kaolenden demirin uzaklaştırılması için kullanılan Pseudomonas, Azotobacter, Bacillus, Aspergillus niger türü mikroorganizmalardır. Bu tür mikroorganizmalar kaolendeki demirin indirgenmesini ürettikleri organik asit ve metabolik ürünlerle sağlamaktadırlar $[4,11]$.

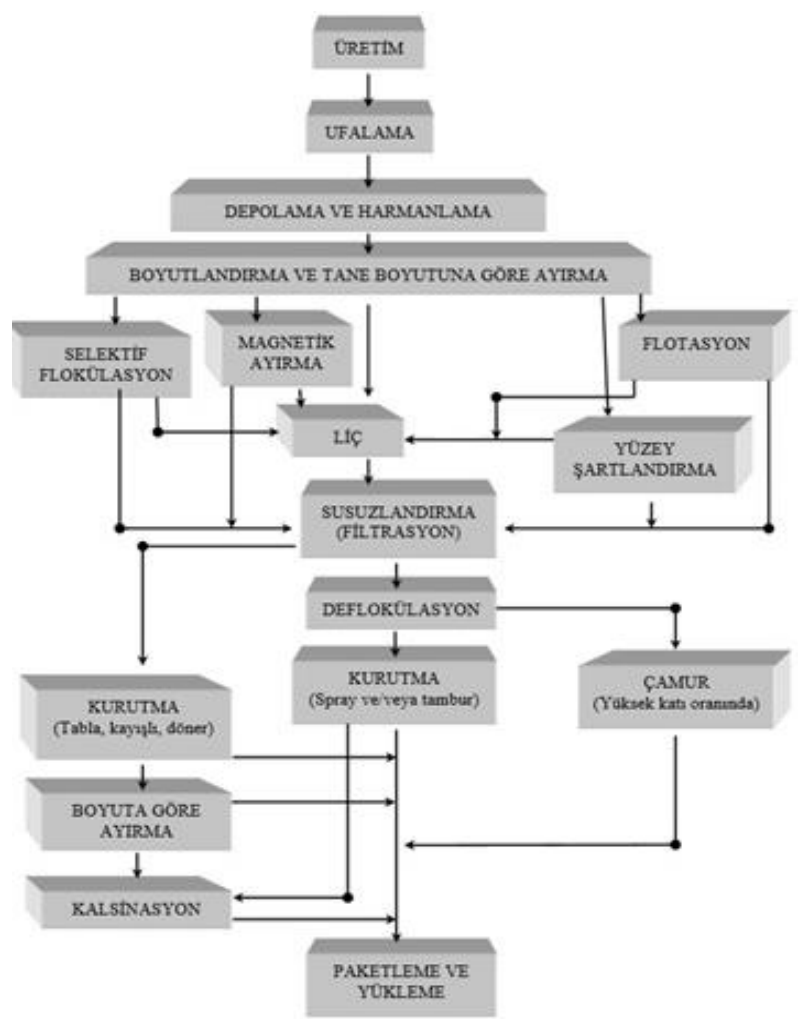

Şekil 2. Kaolenin yaş zenginleștirme yöntemlerini içeren genel akım şeması örneği $[9,12]$

Aspergillus niger glukonik asit, oksalik asit, sitrik asit vb. gibi çeşitli organik asitleri üretirler. Ürettiği enzimler ise; proteaz, pektinaz, selüloz invertaz, amiloglukozidaz ve amilazlardır $[13,14]$. Aspergillus niger fungusu ile biyoliç işlemleri, direkt ve/veya indirekt olarak gerçekleştirilir ve bu süreçlerde çeşitli organik asitler ve metabolik ürünler etkili olmaktadır [14-16].

$\mathrm{Bu}$ çalışmada, kaolen cevherinin Aspergillus niger ile biyoliçinde $\mathrm{Fe}_{2} \mathrm{O}_{3}$ uzaklaştırma verimi ve fungus gelişimi üzerine katı oranı, sükroz oranı ve farklı sürelerde katı ilavesinin etkileri araştırılmıștır.

\section{Materyal ve Metot}

\subsection{Kaolen Numunesi}

Deneysel çalışmalarda kullanılmak üzere BilecikSöğüt bölgesi kaolen cevher yatağından yaklaşık 40 kg kaolen temsili olarak alınmıştır. Kaolen numunesi çeneli kırıcıdan geçirilerek boyut küçültme işlemine tâbi tutulmuştur. Bu işlemin ardından daha önceki çalıșmalar da dikkate alınarak alümina bilyalı değirmende numunenin \%100'ü $106 \mu \mathrm{m}$ altına geçecek șekilde öğütülmüştür. Ögütülmüş numunenin $\mathrm{d}_{80}$ ve $\mathrm{d}_{50}$ boyutları sırasıyla $65 \mu \mathrm{m}$ ve $25 \mu \mathrm{m}$ 'dur.

Kaolen numunesinin tam kimyasal analizi Afyon Kocatepe Üniversitesi Mühendislik Fakültesi Maden 
Mühendisliği Bölümü Akredite Doğaltaş Analiz Laboratuvarında yaptırılmıștır. Kaolen cevherinin kimyasal analizi Rigaku marka ZSX Primus 2 model XRF cihazı ile belirlenmiştir. Kaolen cevherinin kimyasal analiz sonucu Tablo 1'de verilmiştir. Kaolen cevherinin kimyasal analiz sonucunda; kaolenin bünyesinde safsızlık olarak bulunan $\mathrm{Fe}_{2} \mathrm{O}_{3}$ oranı $\% 0,82$ 'dir.

Tablo 1. Kaolen numunesinin kimyasal analizi

\begin{tabular}{cccc}
\hline Bileşik & \% & Bileşik & \% \\
\hline $\mathrm{SiO}_{2}$ & 66,83 & $\mathrm{MgO}$ & 0,16 \\
$\mathrm{Al}_{2} \mathrm{O}_{3}$ & 21,79 & $\mathrm{P}_{2} \mathrm{O}_{5}$ & 0,07 \\
$\mathrm{~K}_{2} \mathrm{O}$ & 5,01 & $\mathrm{SO}_{3}$ & 0,06 \\
$\mathrm{Fe}_{2} \mathrm{O}_{3}$ & 0,82 & $\mathrm{SrO}$ & 0,03 \\
$\mathrm{TiO}_{2}$ & 0,39 & $\mathrm{Cl}$ & 0,02 \\
$\mathrm{BaO}$ & 0,24 & $\mathrm{Rb}_{2} \mathrm{O}$ & 0,01 \\
$\mathrm{Na} \mathrm{N}_{2} \mathrm{O}$ & 0,17 & Kizdırma kaybı & 4,20 \\
$\mathrm{CaO}$ & 0,17 & Diğer & 0,03 \\
\hline
\end{tabular}

Kaolen cevherinin X-Işınları Difraktometre (XRD) analizi, SDÜ Jeoloji Mühendisliği Bölümü Jeotermal Enerji, Yeraltı Suyu ve Mineral Kaynakları Lab.'da bulunan PANalytical marka PW3040/X'Pert Pro model XRD cihazı ile gerçekleştirilmiştir. Kaolen cevherinde başlıca mineraller olarak kaolinit $\left(\mathrm{Al}_{2} \mathrm{Si}_{2} \mathrm{O}_{5}(\mathrm{OH})_{4}\right)$, kuvars $\left(\mathrm{SiO}_{2}\right)$ ve mikroklin $\left(\mathrm{KAlSi}_{3} \mathrm{O}_{8}\right)$ belirlenmiştir.

\subsection{Mikroorganizma ve Gelişme Ortamı}

Saf halde temin edilen Aspergillus niger fungusu, steril petrilere hazırlanan patato dekstroz agar katı besiyeri ortamına sürme yöntemi ile ekim yapılmış (Şekil 3a) ve $30{ }^{\circ} \mathrm{C}$ sıcaklıkta inkübatörde 10 gün boyunca bekletilerek gelişimleri sağlanmıştır (Şekil 3b). Daha sonra $A$. niger fungusu $\mathrm{KH}_{2} \mathrm{PO}_{4}(0,5 \mathrm{~g} / \mathrm{l})$, $\mathrm{MgSO}_{4} .7 \mathrm{H}_{2} \mathrm{O}(0,025 \mathrm{~g} / \mathrm{l}), \mathrm{KCl}(0,025 \mathrm{~g} / \mathrm{l}), \mathrm{NaNO}_{3}(1,5$ $\mathrm{g} / \mathrm{l})$, maya özü $(1,6 \mathrm{~g} / \mathrm{l})$ ve sükroz (100 g/l) içeren sıvı besiyeri ortamına ekim yapılarak geliştirilmiştir. Sıvı besiyeri ortamında geliştirme işleminden önce besiyeri ortamı $1 \mathrm{~atm}$ basınç altında $121^{\circ} \mathrm{C}$ sıcaklıkta $15 \mathrm{dk}$. boyunca otoklavda bekletilerek sterilizasyon işlemi gerçekleştirilmiştir. Sterilizasyon işleminin ardından steril kabinde besiyeri ortamına ekim yapılmıștır. Fungusun sıvı besiyeri ortamında gelișimi yaklaşık olarak 5-7 gün arasında sürmektedir. Bu süre boyunca $125 \mathrm{~d} / \mathrm{dk}$. ve $30^{\circ} \mathrm{C}$ sıcaklığa ayarlanmış çalkalamalı inkübatörde bekletilmiştir.
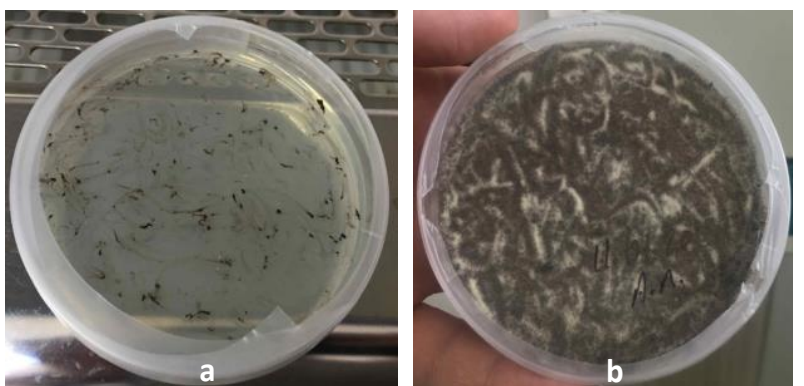

Şekil 3. A. niger fungusunun patato dekstroz agarda a) sürme yöntemi ile ekim yapıldıktan sonra ve b) 10 . gün sonunda gelişim görünümleri

\subsection{Deneysel Çalışmalar ve Analiz Yöntemleri}

Biyoliç deneyleri, $500 \mathrm{ml}$ hacimli Erlenmeyer flasklarda 247,5 ml besiyeri ortamına 2,5 ml fungus aşılama ve \%1-10 (ağırlık/hacim) katı oranında kaolen ilavesi yapılarak gerçekleștirilmiştir. Erlenmeyerlere ekim (fungus ilavesi) yapılmadan önce çözelti, $1 \mathrm{~atm}$ basınç altında $121^{\circ} \mathrm{C}$ sıcaklıkta 15 $\mathrm{dk}$. boyunca otoklavda bekletilerek steril hale getirilmiştir. Daha sonrasında erlenmeyerlerde yaklaşık $1 \times 10^{6}$ ile $1,5 \times 10^{6}$ spor/ml aralığında fungus olacak şekilde steril şartlarda ekim yapılmıştır. Erlenmeyerler $30{ }^{\circ} \mathrm{C}$ sicaklık ve 125 d/dk.'ya ayarlanmış çalkalamalı inkübatöre yerleștirilmiştir. Fungus içermeyen kontrol deneyleri de steril şartlarda yapılmıştır.

Deneyler boyunca steril şartlarda periyodik olarak üç günde bir $5 \mathrm{ml}$ çözelti erlenmeyerlerden alınmıştır. Alınan örnek numuneler üzerinde $\mathrm{pH}$, fungus kuru ağırlığı ve demir analizleri gerçekleştirilmiştir. Numunelerin $\mathrm{pH}$ ölçümlerinde Eutech Ins. marka pH700 model pH metre kullanılmıştır. İlk ekim yapılırken fungus sayısı, direkt sayım yöntemi ile SOIF marka trinoküler mikroskopta Thoma lamı kullanılarak belirlenmiştir. Alınan numunelerden katıyı uzaklaştırmak için numuneler 10 dk. 4100 d/dk.'de santrifüj edilmiştir. Katı kısmı uzaklaştırılmış örnek numunelerin demir analizleri Perkin Elmer marka AA800 model AAS cihazı ve Perkin Elmer marka Optima 5300DV model ICP-OES cihazında yapılmıştır.

\section{Bulgular ve Tartışma}

\subsection{Katı Oranının Etkisi}

Aspergillus niger fungusu ile kaolenden demir giderimine katı oranının etkisini belirlemek amacıyla farklı katı oranlarında (\%1-10 ağırlık/hacim) ve sükroz (\%10 ağırlı/hacim) içeren ortamda deneyler gerçekleştirilmiştir. Katı oranının $\mathrm{Fe}_{2} \mathrm{O}_{3}$ giderim verimine etkisi Şekil 4'de gösterilmiștir. En yüksek $\mathrm{Fe}_{2} \mathrm{O}_{3}$ giderimi \%1 katı oranında 336 saat sonunda \%52,47'dir. Katı oranının artıșı ile $\mathrm{Fe}_{2} \mathrm{O}_{3}$ giderim verimleri azalmıştır. Örneğin \%10 katı oranında $\mathrm{Fe}_{2} \mathrm{O}_{3}$ giderimi \%18,51'e düşmüştür. $\mathrm{Bu}$ bakımdan katı oranının artışıyla biyoliç işleminin yavaş ilerlemesi nedeniyle aynı seviyede $\mathrm{Fe}_{2} \mathrm{O}_{3}$ giderimi elde etmek için gerekli biyoliç süresi artmaktadır. Fungus içermeyen $\% 1$ ve $\% 5$ katı oranlarında yapılan kontrol testlerinde ise $\mathrm{Fe}_{2} \mathrm{O}_{3}$ giderimi sirasıyla \%6,22 ve $\% 2,89$ 'dur. Hosseini vd. [17], katı oranının artması sonucunda ortam viskozitesinin arttığını, artan viskozitenin organik asitlerin/bileşiklerin etkili olabilmesi için mevcut yüzey alanını azaltan kil minerali agregasyonunda artış oluşturduğunu, bu durumdan dolayı kil yüzeylerine bu organik bileşiklerin yeterince temas edemediğinden demir çözünme veriminin düştüğünü belirtmişlerdir. 
Biyoliç deneyleri boyunca tüm katı oranlarında $\mathrm{pH}$ giderek azalmıştır (Şekil 5). Katı oranının artması yani ortamda kaolen cevherinin daha fazla bulunması ile ortam pH'ı daha az düșmüştür. Bunun muhtemel nedenleri arasında; katı oranının artışıyla ortamda fungus tarafından organik asit üretiminin yavaşlaması veya asit tüketen minerallerin ortamda daha fazla bulunması olabilir. Sükroz içeren ortamda en fazla pH düşüşü \%1 katı oranında yapılan deneyde olup, 336 saat sonunda ortamin pH'ı 3,75'e düşmüştür. Kontrol testlerinde ise deney boyunca pH'da belirgin bir değişim gözlenmemiş olup, \%1 katı oranında 336 saat sonunda pH 5,88'e düşmüştür. Cameselle vd. [18] tarafından yapılan farklı katı oranlarında (\%1-3) pH'ın demir çözünmesine etkilerinin incelendiği bir biyoliç çalışmasında, $\mathrm{pH}$ 2'de \%3 katı oranında daha yüksek demir giderimi sağlanmıştır.

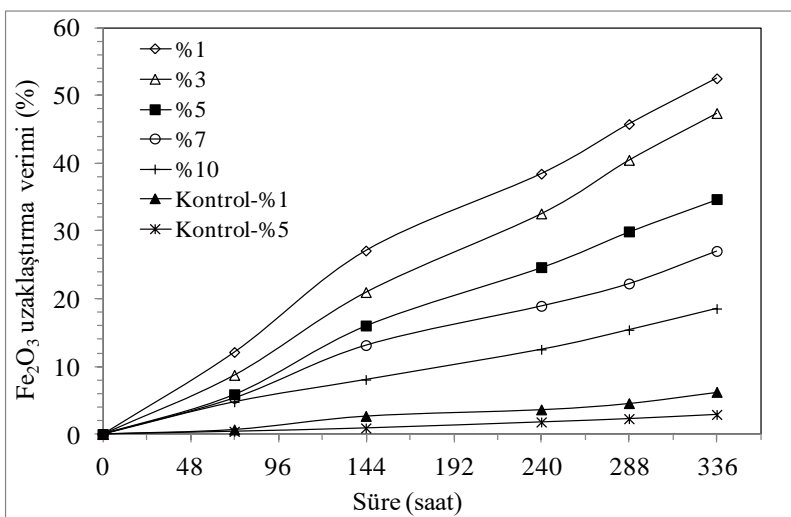

Şekil 4. A. niger ile farklı katı oranlarında (\%1-10) ve sükroz (\%10) içeren ortamda yapılan biyoliç deneylerinde kaolenden $\mathrm{Fe}_{2} \mathrm{O}_{3}$ giderimi

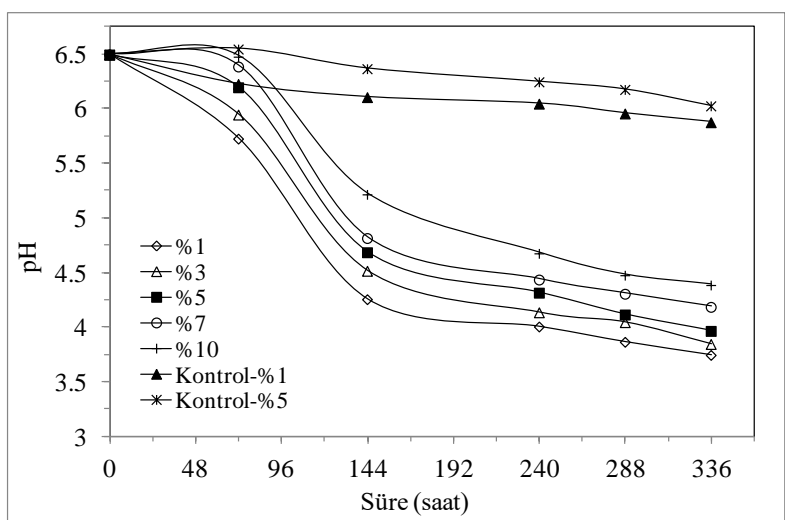

Şekil 5. A. niger ile farklı katı oranlarında (\%1-10) ve sükroz (\%10) içeren ortamda yapılan biyoliç deneyleri boyunca $\mathrm{pH}$ değişimleri

Farklı katı oranlarında yapılan biyoliç deneylerinde $A$. niger fungusunun gelișimini takip etmek amacıyla fungus kuru ağırlıkları incelendiğinde en fazla $A$. niger gelişimi \%1 katı oranında gerçekleşmiştir (Şekil 6). Fungus gelişimine benzer şekilde $\% 1$ katı oranında ortam pH'ının da daha düşük olduğu görülmektedir (Şekil 5 ve 6). Katı oranının artışıyla fungus gelişiminin azaldığı gözlenmiştir. Bununda en önemli sebebi ortamda kaolen miktarının artışı ile ortamda çözünmüş metal konsantrasyonunun artmasının fungus üzerinde toksik etki oluşturması ve/veya artan katı taneciklerin fungusa mekaniksel zarar vermesi olarak söylenebilir. Tüm katı oranlarında biyoliç deneyleri boyunca fungus gelişimi devam etmiştir (Şekil 6). Deney sonunda en yüksek kuru fungus ağırlık değeri, \%1 katı oranında yaklaşık $16 \mathrm{~g} / \mathrm{L}$ olarak saptanmıştır.

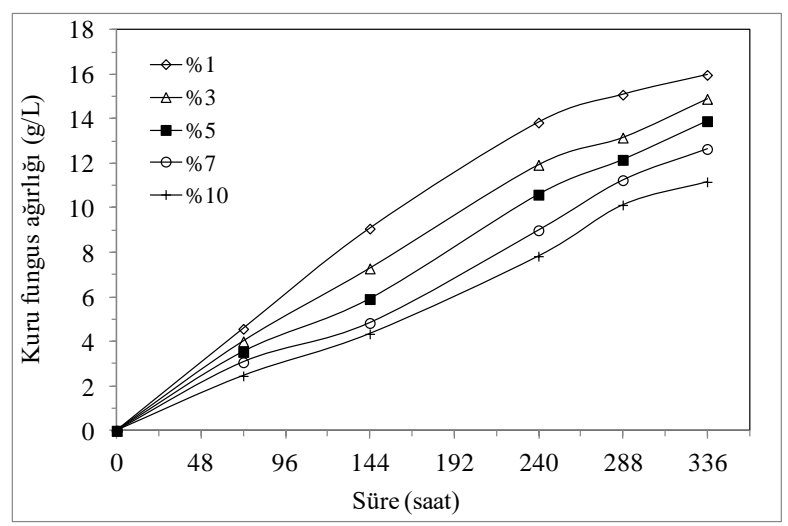

Şekil 6. A. niger il farklı katı oranlarında (\%1-10) ve sükroz (\%10) içeren ortamda yapılan biyoliç deneyleri boyunca fungus gelişimi

\subsection{Sükroz Oranının Etkisi}

Aspergillus niger fungusu ile farklı sükroz oranlarında yapılan biyoliç deneyleri, $50 \mathrm{~g} / \mathrm{L}$ ile $200 \mathrm{~g} / \mathrm{L}$ aralığında (\%5-20 ağırlı/hacim) sükroz içeriğine sahip besiyeri ortamlarında \%5 katı oranında uygulanmıştr. $\mathrm{Bu}$ testlerde deney boyunca elde edilen $\mathrm{Fe}_{2} \mathrm{O}_{3}$ giderim verimleri Şekil 7'de gösterilmiştir.

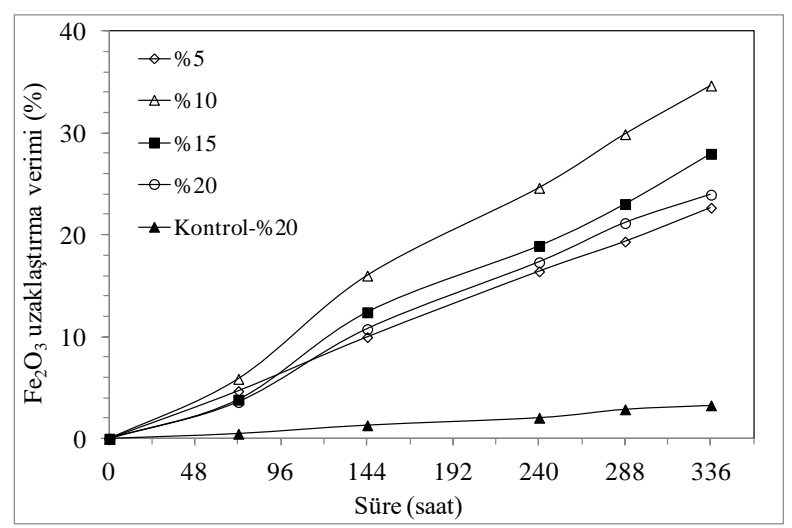

Şekil 7. A. niger ile farklı sükroz oranlarında (\%5-20) yapılan biyoliç deneylerinde kaolenden $\mathrm{Fe}_{2} \mathrm{O}_{3}$ giderimi (Katı oranı: \%5)

En yüksek $\mathrm{Fe}_{2} \mathrm{O}_{3}$ giderimi \%10 sükroz oranında yapılan deneyde olup, 336 saat sonunda $\% 34,66$ 'dır. Bu orandan daha düşük (\%5) veya daha yüksek (\%15 ve $\% 20$ ) sükroz oranlarında yapılan deneylerde ise $\mathrm{Fe}_{2} \mathrm{O}_{3}$ giderimleri azalmıştır. Ranjbar vd. [19], \%2,2 Fe içeriğine sahip kaolenin biyoliçi üzerine \%3 katı oranı ve \%5-13 sükroz oranı içeren şartlarda yaptıkları bir çalışmada 10. gün sonunda $\% 5$ ve $\% 13$ sükroz oranında sırasıly $\% 38,8$ ve $\% 22,7 \quad \mathrm{Fe}$ uzaklaştırmışlardır. Şeker konsantrasyonundaki azalmanın ve oksalik asit konsantrasyondaki artışın 
çözünmüş demir konsantrasyonunda artışa neden olduğunu belirtmişlerdir. Aghaie vd. [20], kaolenden $\% 7$ sükroz oranında \%67,4 Fe uzaklaştırma verimi elde etmișlerdir ve sükroz konsantrasyonun artışının demir çözünme verimini olumsuz yönde etkilediğini ancak oksalik ve sitrik asit üretiminin ise olumlu yönde etkilendiğini ifade etmişlerdir. Deveci ve Özyurt [21], sükroz oranı artışının organik asit üretiminde azalmaya neden olduğunu bunun nedeninin de substrat inhibisyonu olduğunu söylemiştir [14]. Substrat inhibisyonu, mikroorganizmaların enzimatik reaksiyonlarının farklılaşması ile ilgili olduğu belirtilmiştir [14, 22].

Farklı sükroz oranlarında yapılan biyoliç deneylerinde, sükroz oranının artmasıyla pH'ın daha fazla düștüğü görülmüștür (Şekil 8). Bunun nedeni olarak sükroz oranının artması ile Aspergillus niger fungusun ortamda daha fazla organik asit ürettiği ve bunun sonucunda da ortam pH'ının daha fazla düştüğü söylenebilir. Sükroz oranı \%10'da pH daha az düşmesine karşın daha yüksek $\mathrm{Fe}_{2} \mathrm{O}_{3}$ giderimi elde edilmesi bakımından $\mathrm{Fe}_{2} \mathrm{O}_{3}$ gideriminde ortam pH'ından ziyade ortamda hangi tür organik asitlerin ve ne kadar konsantrasyonlarda oldukları daha önemlidir.

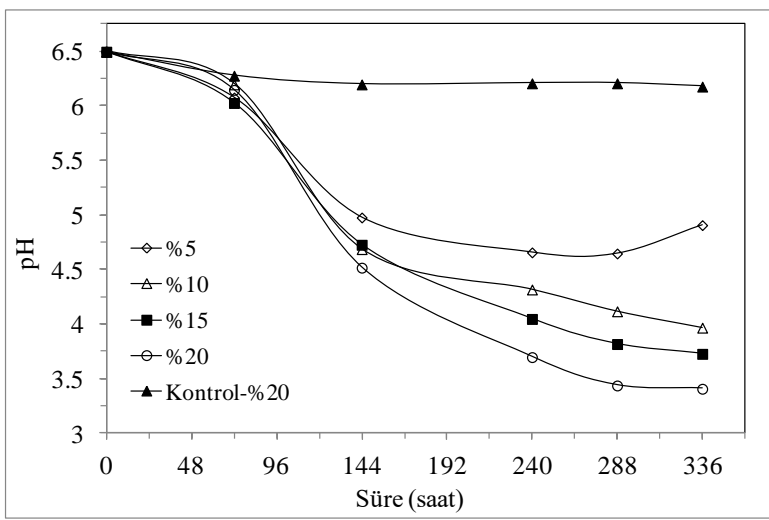

Şekil 8. Farklı sükroz oranlarında (\%5-20) yapılan biyoliç deneyleri boyunca $\mathrm{pH}$ değișimleri (Katı oranı: \%5)

Aspergillus niger fungusunun farklı sükroz oranlarında yapılan biyoliç deneyleri boyunca en yüksek $A$. niger gelişimi \%15 sükroz oranındadır (Şekil 9). \%5 sükroz oranı dışındaki diğer sükroz oranlarında birbirine yakın fungus gelişimi olmuştur. Aghaie vd. [20], A. niger gelişiminin sükroz oranı ile orantılı olmadığını belirtmişlerdir. Atik [14], biyoliç işlemlerinde $A$. niger'ın aktivasyonunu etkileyebilecek birçok değişkenin olduğunu fakat en önemli iki değişkenin katı oranı ve sükroz oranı olduğunu belirtmiştir.

\subsection{Farklı Sürelerde Cevher İlavesinin Etkisi}

Sükroz içeren biyoliç ortamına farklı sürelerde kaolen ilavesi ile yapılan deneysel çalışmalarda, kaolen cevheri 0. saat, 72. saat, 144. saat, ve 240. saatte ortama $\% 1$ ve $\% 5$ katı oranında ilave edilmiştir. Bu testler \%10 sükroz oranı, $30{ }^{\circ} \mathrm{C}$ ve 125 d/dk. karıștırma hızında gerçekleştirilmiştir. $\mathrm{Bu}$ şartlarda $\% 1$ ve \%5 katı oranında elde edilen kaolenden $\mathrm{Fe}_{2} \mathrm{O}_{3}$ giderim verimlerinin değişimi sırasıyla Şekil 10 ve 11 'de verilmiştir.

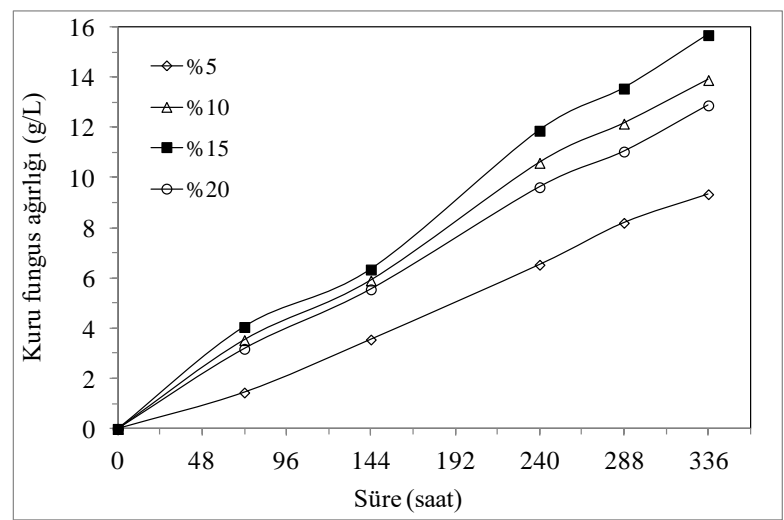

Şekil 9. Farklı sükroz oranlarında (\%5-20) yapılan biyoliç deneyleri boyunca fungus gelişimi (Katı oranı: \%5)

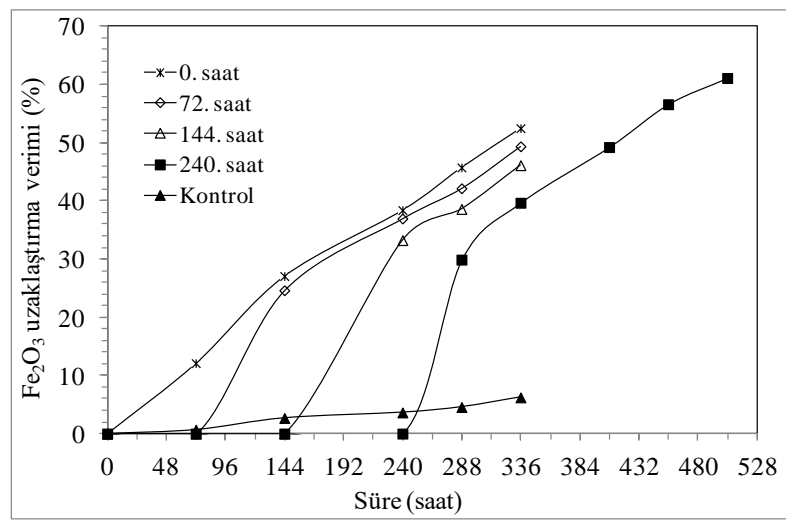

Şekil 10. A. niger ile yapılan biyoliç deneylerinde farklı sürelerde \%1 katı oranında kaolen ilavesi ile elde edilen $\mathrm{Fe}_{2} \mathrm{O}_{3}$ giderimi (Sükroz oranı: \%10)

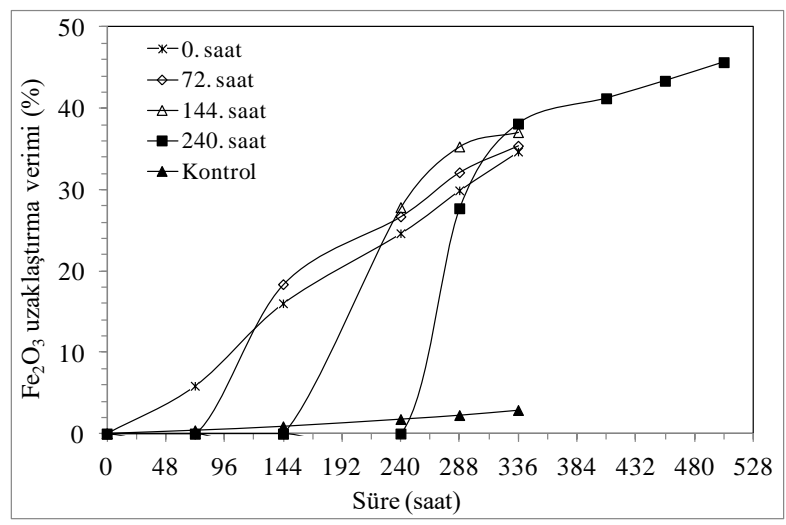

Şekil 11. A. niger ile yapılan biyoliç deneylerinde farklı sürelerde \%5 katı oranında kaolen ilavesi ile elde edilen $\mathrm{Fe}_{2} \mathrm{O}_{3}$ giderimi (Sükroz oranı: \%10)

Aspergillus niger ile kaolenin biyoliçi, kültür ortamına cevher ve fungusun aynı anda ilavesi ile veya fungus gelişimi sağlandıktan sonra cevherin ilavesi ile gerçekleştirilebilir. Cevher ve fungus aynı anda ortama ilave edildiğinde, çözünmüş demir iyonları ve katı tanecikler fungusun gelişimini ve metabolik faaliyetlerini olumsuz etkileyerek sonuçta $\mathrm{Fe}_{2} \mathrm{O}_{3}$ giderim verimini düşürebilir. Bu nedenle çözünmüş 
metal iyonlarının mikroorganizmanın ortamda ilk gelişimine olumsuz etkisini azaltmak amaciyla fungus cevher içermeyen şartlarda geliștirilir ve daha sonra bu kültür ortamına kaolen cevheri ilave edilerek demirin çözünmesi sağlanabilmektedir. Fungus gelişiminden sonra kaolen cevherinin ilavesi daha agresif liç koşullarının oluşmasını, dolayısıyla daha yüksek $\mathrm{Fe}_{2} \mathrm{O}_{3}$ giderim verimini sağlayabilir [18].

En yüksek $\mathrm{Fe}_{2} \mathrm{O}_{3}$ giderim verimi, \%1 katı oranında kaolen ilavesinin 240. saatte yapıldığı testte 504 saat sonunda \%61,09 olarak elde edilmiștir. Bașlangıçta (0. saatte) kaolen ilave edildiğinde 14 gün süren biyoliç işlemi sonunda \%52,47 $\mathrm{Fe}_{2} \mathrm{O}_{3}$ giderimi sağlanırken, 10 günlük fungusun gelişimi sonrası kaolen ilavesi yapıldıktan itibaren 11 gün sonunda $\% 61,09 \mathrm{Fe}_{2} \mathrm{O}_{3}$ giderimi sağlanmıştır (Şekil 10). Bu durum fungusun gelişim aşamasında ortamda bulunan inorganik maddelerin varlığı nedeniyle metabolik aktivitesinin azaldığını göstermektedir. $A$. niger fungusu ile biyoliç deneylerinde 336 saat sonunda \%1 katı oranında en yüksek giderim 0 . saatte kaolen ilavesinin yapıldığı testte elde edilirken, $\% 5$ katı oranında ise 240 . saatte kaolen ilave edilen testte sağlanmıştır (Şekil 10 ve 11). Bu durum katı oranının fungusun biyoliç performansına olumsuz etkisini göstermektedir. \%5 katı oranında kaolen ilavesi yapılan tüm testlerde $\% 1$ katı oranına göre daha düşük demir giderimleri gerçekleşmiştir.

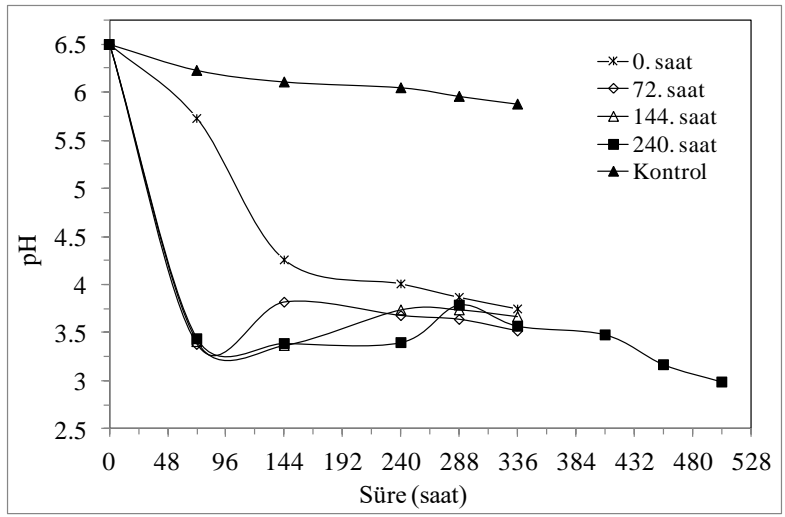

Sekil 12. A. niger ile farklı sürelerde $\% 1$ katı oranında kaolen ilavesi ile yapılan biyoliç deneyleri boyunca pH'ın değișimi (Sükroz oranı: \%10)

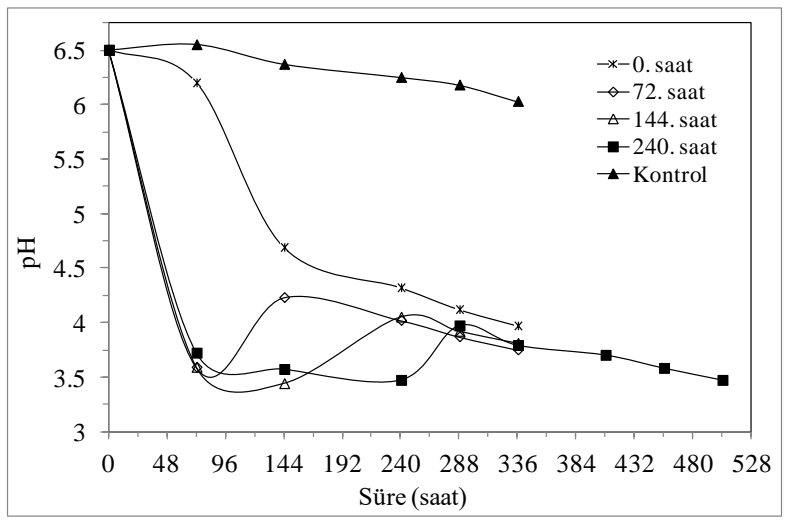

Şekil 13. A. niger ile farklı sürelerde $\% 5$ katı oranında kaolen ilavesi ile yapılan biyoliç deneyleri boyunca pH'ın değișimi (Sükroz oranı: \%10)
Cameselle vd. [18] tarafından yapılan bir çalışmada; A. niger 1120 fungusu ile farklı sürelerde $(0$. ve 3 . günde) \%1-3 katı oranında kaolen cevherinin ilave edildiği biyoliç işleminde $\mathrm{pH} 2$ 'de 3 . günde cevher ilavesi ile yapılan testte 10. gün sonunda \%100 Fe çözünmesi sağlanmıştır. $\mathrm{Bu}$ çalışmada fungusun gelişimin erken aşamalarında inorganik maddelerin varlığına bağlı olarak metabolik aktivitesinin azaldığı belirtilmiştir [18]. Şekil 12 ve 13'de görüldüğü üzere cevher ilavelerinin yapıldığı süreden sonra $\mathrm{pH}$ değerlerinde bir artış görülmüştür. Cevher ilavesinin yapıldığı sürelerde $\mathrm{pH}$ değerlerindeki artışın, cevher içerisindeki muhtemel asit tüketen mineraller nedeniyle olduğu düşünülmektedir.

\section{Sonuç}

Bu çalışma kapsamında, Bilecik-Söğüt bölgesi kaolen cevherleşmesinden temsili olarak alınan kaolen cevheri üzerinde Aspergillus niger fungusu kullanılarak biyoliç deneyleri uygulanmıștır. Kaolen cevherinin biyoliçinde $\mathrm{Fe}_{2} \mathrm{O}_{3}$ giderim verimi ve fungus gelişimine katı oranı, sükroz oranı ve farklı sürelerde katı ilavesinin etkileri belirlenmiştir.

Fungus kullanılarak kaolenden $\mathrm{Fe}_{2} \mathrm{O}_{3}$ gideriminde katı oranının etkisinin araştırıldığı deneysel çalışmalarda, deneyler boyunca demir uzaklaştırma verimlerinde artış olmuş, en yüksek $\mathrm{Fe}_{2} \mathrm{O}_{3}$ uzaklaştırma verimi \%1 (ağırlık/hacim) katı oranında 14 günün sonunda $\% 52,47$ olarak elde edilmiştir. Katı oranının artışıyla demir giderim verimlerinin azaldığı gözlemlenmiştir. Bunun muhtemel nedeni olarak; katı oranının artması sonucunda ortam viskozitesinin arttığl, artan viskozitenin kaolen taneciklerinin agregasyonunda artış oluşturduğu, bu nedenle mineral tanelerinin yüzey alanının azaldığı ve neticede mineral tanelerinin yüzeylerine organik asitler/bileşikler yeterli seviyede temas edemediğinden demir çözünme veriminin azaldığı düşünülmektedir.

Sükroz oranının $\mathrm{Fe}_{2} \mathrm{O}_{3}$ giderim verimine etkisinin incelendiği deneylerde en yüksek $\mathrm{Fe}_{2} \mathrm{O}_{3}$ giderimi \%10 (ağırlı/hacim) sükroz içeren ortamda \%34,66 olarak elde edilmiştir. Sükroz oranının artışı ile giderim verimlerinin azaldığı gözlemlenmiştir. Sükroz oranı artışının substrat inhibisyonu nedeniyle fungusun gelişiminde ve organik asit üretiminde azalmaya neden olduğu söylenebilir. Farklı sürelerde kaolen cevheri ilavesinin $\mathrm{Fe}_{2} \mathrm{O}_{3}$ giderim verimine etkisi üzerine yapılan çalışmalarda en yüksek $\mathrm{Fe}_{2} \mathrm{O}_{3}$ giderimi, 10 günlük fungusun gelişimi sonrası $\% 1$ oranında kaolen ilavesi yapıldıktan itibaren 11 gün sonunda \%61,09 olarak sağlanmıștır. Fungus gelişimi sonrası kaolen cevherinin ilavesi kaolenden demir giderimine olumlu etki yapmıştır. 


\section{Teşekkür}

Bu çalışmayı FYL-2018-6148 no'lu proje ile destekleyen Süleyman Demirel Üniversitesi Bilimsel Araştırma Projeleri Koordinasyon Birimi Başkanlığı'na teşekkür ederiz.

\section{Kaynakça}

[1] Hosseini, M.R., Ahmadi, A., 2015. Biological Beneficiation of Kaolin: A Review on Iron Removal. Applied Clay Science, 107, 238-245.

[2] Eygi, M.S., 2009. Seramikte kaolen kullanımının polielektrolit katkısıyla geliştirilmesi. İstanbul Teknik Üniversitesi, Fen Bilimleri Enstitüsü, Yüksek Lisans Tezi, 195s, İstanbul.

[3] DPT Madencilik Özel İhtisas Komisyonu, 2001. Sekizinci Beş Yıllık Kalkınma Planı Raporu, Endüstriyel Hammaddeler Alt Komisyonu Toprak Sanayi Hammaddeleri I, Ankara.

[4] Akçil, A., Tuncuk, A., 2006. Kaolenlerin Safsızlaştırılmasında Kimyasal ve Biyolojik Yöntemlerin İncelenmesi. Kibited, 1(2), 59-69.

[5] GMKA Güney Marmara Kalkınma Ajansı, 2011. Balıkesir İli Maden Potansiyeline Bir Bakış.

[6] Shelobolina, E., Pickering, S.M., Kogel, J.E., 2002. The Role of Bacterial Alteration in Whitening and Iron Removal from Georgia's Commercial Kaolin Clays. SME Annual Meeting, 25-27 February, Arizona, (CD-ROM).

[7] Koca, S, 1992. Kaolin ve alunitin reaktif adsorpsiyon mekanizmalarının flotasyon reaktiflerinin seçimine etkisi. Anadolu Üniversitesi, Fen Bilimleri Enstitüsü, Doktora Tezi, 156s, Eskişehir.

[8] Bozdoğan, İ., 2006. Türkiye Kaolin Sektörünün Analizi: Güncel Durum ve Sorunlar. Kibited, 1(2), 73-80.

[9] Tatar, İ., 2012. Alunitli kaolinlerden değişik zenginleştirme yöntemleriyle elde edilen ürünlerin kullanım alanlarının belirlenmesi. Dumlupınar Üniversitesi, Fen Bilimleri Enstitüsü, Yüksek Lisans Tezi, 201s, Kütahya.

[10] Çiftçi, H., 2008. Refrakter altın cevher ve konsantrelerinin biyooksidasyonu. Süleyman Demirel Üniversitesi, Fen Bilimleri Enstitüsü, Doktora Tezi, 356s, Isparta.

[11] Lee, E.Y., Cho, K.S., Ryu, H.W., 2002. Microbial Refinement of Kaolin by Iron-Reducing Bacteria. Applied Clay Science, 22, 47-53.

[12] Murray, H.H., 2007. Occurrences, Processing and Application of Kaolins, Bentonites, PalygorskiteSepiolite and Common Clays. Applied Clay Mineralogy, 33(39), 85-108.

[13] Jin, B., Warburton, K., Mc-Garry, U.P., Ramage, D., 2002. Integrated Biosystems for Sustainable
Development. Rural Industries Research and Development Corporation, Rural Industries Research and Development Corporation Publication No 01/174, Rural Industries Research and Development Corporation Project No MS001-14, 181p.

[14] Atik, S., 2015. Biyoliç yöntemiyle lateritik cevherden nikel kazanımı. Süleyman Demirel Üniversitesi, Fen Bilimleri Enstitüsü, Yüksek Lisans Tezi, 137s, Isparta.

[15] Berthelin, J., 1983. Microbial Geochemistry. Ss. 223-262. Krumbein, W.E., (Ed.), Microbial Weathering Processes. Blackwell, Oxford, 375s.

[16] McKenzie, L., 1987. Technology and Research Applications Review. Applied Engineering, 245, Texas.

[17] Hosseini, M.R., Pazouki, M., Ranjbar, M., Habibian, M., 2007. Bioleaching of Iron from Highly Contaminated Kaolin Clay by Aspergillus niger. Appl. Applied Clay Science, 37, 251-257.

[18] Cameselle, C., Ricart, M.T., Nunez, M.J., Lema, J.M., 2003. Iron Removal from Kaolin. Comparison between "In situ" and "Two-stage" Bioleaching Processes. Hydrometallurgy, 68, 97-105.

[19] Ranjbar, M., Aghaie, E., Hosseini, M.R., Pazouki, M., Ghavipanjeh, F., 2007. Optimization of Kaolin Bioleaching by Aspergillus niger. Advanced Materials Research, 20(21), 115-118.

[20] Aghaie, E., Pazouki, M., Hosseini, M.R., Ranjbar, M., Ghavipanjeh, F., 2009. Response Surface Methodology (RSM) Analysis of Organic Acid Production for Kaolin Beneficiation by Aspergillus niger. Chemical Engineering Journal, $147,245-251$.

[21] Deveci, E.Ü., Özyurt, M., 2011. Portakal Hidrolizatı ve Melas İçerikli Besiyeri Ortamında Sitrik Asit Üretimine Başlangıç Toplam Şeker Derişiminin Etkisi. Biyoloji Bilimleri Araştırma Dergisi, 4, 43-47.

[22] Muhtar, S., 2000. Aspergillus niger kullanılarak melastan sitrik asit üretimi. Gazi Üniversitesi, Fen Bilimleri Enstitüsü, Yüksek Lisans Tezi, 73s, Ankara. 